\title{
Üniversitelerin Bilgi ve Belge Yönetimi Bölümleri'nin “Engellilik Farkındalığı” Üzerine Bir Araştırma
}

\author{
A Research on "Disability Awareness" in Information and \\ Records Management Departments of Universities
}

\section{Fatoş SUBAŞIOĞLU*}

\section{Öz}

Tüm insanlar eşit doğar ve topluma katılımda eşit haklara sahiptir. Ancak gerçek yaşamda kimi gruplar, sosyal durumları, bilişsel ve fiziksel farklılıkları açısından söz konusu haklara sahip olamamaktadırlar. Engelliler de bu grubun bir kategorisini oluşturmaktadır. Engelli bireylerin sorunları, hiç kuşkusuz küresel insan hakları sorunudur ve engellilikle ilgili en önemi nokta, toplumda, "farkındalığın yaratılması", "anlaşılma" gereksinimlerinin karşılanmasıdır. Son yıllarda gelişmiş veya gelişmekte olan ülkeler, engel türü ne olursa olsun, toplumsal yaşam içinde engelli tabanlı ayrımcılıkla mücadele etmek, toplumsal farkındalığı artırmak için engelli katıımlı eğitim, bilgiye erişim, sosyal politikalar, ekonomi gibi modellerin oluşturulması gerektiğinde birleşmektedirler. Bu çalışmanın amacı, toplumsal ve bireysel gereksinimler doğrultusunda bilgi hizmeti sunan kütüphanecileri yetiştiren ülkemiz Bilgi ve Belge Yönetimi Bölümlerinin engelli farkındalıklarının eğitim programlarına yansıyan yönlerini saptamaya yöneliktir.

Anahtar sözcükler: Kütüphanecilik ve bilgi bilim, Eğitim, Ders programları, Engelliler

* Doç.Dr.; Ankara Üniversitesi Dil ve Tarih Coğrafya Fakültesi Bilgi ve Belge Yönetimi Bölümü, 06100 Sıhhıye, Ankara (fsubasioglu@hotmail.com) 


\section{Abstract}

Humans have equal rights in joining the society. However, in real life some groups of people cannot exercise these rights fully, with regard to the diversities in their social, cognitive and physical conditions. Disabled people constitute one of those groups. The problem of disabled ones is certainly a global human rights problem, and the most important point concerning the disabled ones lies in "creating awareness" In recent years developed and developing countries agree on the struggle against disabled-based discrimination, and are in need of the models such as disabled-participated education, information retrieval, social policies and utilization of economic policy tools in their societies. The aim of this study is to determine the disabled awareness to be reflected in the curricula of Information and Records Management Departments in our country.

Keywords: Library and information science, Education, Curricula, Disabled people

\section{Giriş}

İnsan toplumsal bir varlıktır, içinde yaşadığı topluma katılarak yaşar. Önemli olan, katııımın varlığı ya da gerekliliği değil, düzeyidir.

Her insan içinde yaşadığı topluma çeşitli düzeylerde katııırken hem toplumsal etkenlerden, hem de kişisel özelliklerden etkilenir ve toplumsal kimliğini, taşıdığı roller ve içinde bulunduğu statüler aracılığıyla kazanıp yansıtır. Bir başka deyişle, bireyin toplumsal işlevselliği, sahip olduğu toplumsal roller ve statülerden etkilenir. Bireyin taşıdığı toplumsal roller, çevreyle kurduğu iletişimin niteliğini; içinde yer aldığı iletişim örüntüsü de toplumsal rollerini yerine getirmede gösterdiği başarıyı etkiler.

Tüm insanlar eşit doğar ve eğitim fırsatlarında, topluma katılımda eşit haklara sahiptir. Ancak gerçek yaşamda kimi gruplar, sosyal durumları, bilişsel ve fiziksel farklılıkları açısından söz konusu haklara sahip olamamaktadır. Engelliler de bu grubun bir kategorisini oluşturmakta ve toplumun diğer bireyleri gibi, günlük yaşamlarında, mesleki gelişmelerine, sosyal refahlarına ilişkin konularda bilgiye gereksinim duymaktadır. İnsan hakları alanındaki başarılı uygulamalar da, çoğunlukla toplum içindeki, engelli ya da engelsiz, bütün bireylere sağlık, eğitim, ulaşım, sosyal güvenlik, istihdam ve 
adalet gibi hizmetlerin yeterli olarak verilip verilmediği ile ölçülmektedir.

\section{Engellilik Nedir?}

Herkes tarafından biliniyormuş gibi görünse de, engelli kavramı bir belirsizliğin ifadesidir. Bireyin fiziksel ve zihinsel işlevlerindeki bozukluk ve bunların hareket yeteneğinde, tutum ve davranışlarında yarattığı eksiklik ve güçlük, onu toplumun diğer bireylerinden farklı kılar. Bu farklılık, engellilerin yaşadığı belirsizlik ve ayrımcılığın da asıl nedenidir. Her türlü ayrımcılığın temelinde farklı olmak, yani "alışılmamış özelliklere" sahip olmak vardır. Fiziksel ve ruhsal işlevlerdeki bozukluklar ve bunların hareket ve davranış yeteneği üzerinde yarattığı sınırlııklar da bireyi toplumdan uzaklaştırır. Toplumsal destek sistemlerinin yetersizliği, toplumun dışlayıcı tutum ve davranışları da engelli bireyin topluma eşit bireyler olarak katılmasını önler (Özürlüler ve yaşam).

Dünya Sağlık Örgütü (WHO) verilerine göre, genel olarak herhangi bir toplumun nüfusunun yaklaşık \% 10'unu, dünyanın 750 milyon ile 1 milyar kişisini (Perelman, 2007) ve Dünya Bankası verilerine göre dünyanın en yoksul toplumlarının nüfusunun \% 20'sini engelli kişiler oluşturmaktadır (Braithwaite ve Mont, 2008). Engellilik, yoksulluğun hem nedeni hem de sonucu olarak değerlendirmektedir. Birleşmiş Milletlerin verilerine göre engelli kişilerin \% 82'si gelişmekte olan ülkelerde, yoksulluk sınırının altında yaşamaktadır. Bu rakam, iç savaş veya doğal afetler sonucu harap olmuş ülkelerde daha yüksektir (Commitment; Russel, 2003).

2000 yılından itibaren dünya nüfusunun beşte dördünün gelişmekte olan ülkelerde yaşayacağı öngörülmüştür. Tüm dünyada varolan ama gelişmekte olan ülkelerin yeni dünya görüşü içinde ele alması gereken pek çok sosyal sorunları mevcuttur. Engellilik bu sosyal sorunların başında gelmektedir (Karataş, 2002, s.43).

"Engellilik", "özürlülük”, "sakatlık" kavramları, bu kavramlar arasındaki farklar ve dünyadaki dağılımı, sıklıkla karşılaşılan başlıklardır. Söz konusu kavramlar arasındaki farkların günlük yaşamda değeri yoktur. Çünkü önemli olan, bireylerin engellilik durumunu tanımlayan kavramlar değil, engelli bireylerin toplumdaki diğer 
bireylere göre farklı hizmet gereksinimlerinin olduğunun bilinmesidir (Şahin, 2004, s.40).

Dünya Sağlık Örgütü* (WHO), özürlülük/engellilik kavramı hakkında hastalık sonuçlarına dayanan, sağlık yönüne ağırlık veren bir tanımlama ve sınıflama yapmıştır:

"Yetersizlik (Impairment): "Sağlık bakımından 'eksiklik / yetersizlik', psikolojik, anatomik veya fiziksel yapı ve fonksiyonlardaki bir noksanlığı veya dengesizliği...”,

Özürlülük (Disability): “...özürlülük / sakatlık', bir noksanlık sonucu meydana gelen ve normal sayılabilecek bir insana oranla bir işi yapabilme yeteneğinin kaybedilmesi ve kısıtlanması durumunu...",

Engellilik (Handicap): “... 'engellilik', bir eksiklik veya sakatık sonucunda, belirli bir kişide meydana gelen ve o kişinin yaş, cinsiyet, sosyal ve kültürel durumuna göre normal sayılabilecek faaliyette bulunma yeteneğini önleyen ve sınırlayan dezavantajlı bir durumu ifade eder."

Birleşmiş Milletler Genel Kurulu'nun Insan Hakları Evrensel Bildirisi'ne Ek 3447 nolu ve 9 Aralık 1975 tarihli Sakat Kişilerin Hakları Beyannamesi'nin 1. maddesindeki "sakat" tanımı şu şekildedir: "Sakat kişi”, normal bir ferdi, kişisel veya sosyal yaşayışında kendi kendine yapması gereken işleri, bedensel veya zihinsel kabiliyetlerinde, kalıtımsal veya sonradan meydana gelen herhangi bir noksanlık sonucu yapamayan kişidir" (Sakat, 1975).

Ülkemizde, Özürlüler ve Bazı Kanun ve Kanun Hükmünde Kararnamelerde Değişiklik Yapılması Hakkında Kanun'un 3(a) maddesinde ise özürlü: "...doğuştan veya sonradan herhangi bir nedenle bedensel, zihinsel, ruhsal, duyusal ve sosyal yeteneklerini çeşitli derecelerde kaybetmesi nedeniyle toplumsal yaşama uyum sağlama ve günlük gereksinimlerini karşılama güçlükleri olan ve korunma, bakım, rehabilitasyon, danışmanlık ve destek hizmetlerine ihtiyaç duyan kişiyi” tanımlamaktadır (Özürlüler ve Bazı, 2005).

${ }^{*}$ World Health Organization-WHO. http://www.who.int/en/ 
2003 yılının son aylarında Özürlüler Şurası'nın kararları doğrultusunda yapılan araştırma sonuçlarına göre; Türkiye'de özürlülük oranı \% 12.29'dur ve nüfusun 8.431.937'sini oluşturmaktadır. Engellilerin ise 3.783.197'sini erkektir. İşitme engelliler binde 37 , dil ve konuşma engelliler binde 38 , zihinsel engelliler binde 48, görme engelliler binde 60, fiziksel engelliler yüzde 1.25, ruhsal ve kronik süreğen hastalığı olanlar yüzde 9.70'dir (Sarıoğlu).

Engelli insanların sorunları, kuşkusuz bir küresel insan hakları sorunudur ve ülkemizde de engellilerin özellikle toplumla bütünleşme yönünde yoğun sorunlar içinde yaşadıkları bilinmektedir. Sorunu adlandırmadan başlayan ve yaşamın pek çok alanına yayılan bu sorunlar, engelli bireylerin içinde yaşadıkları toplumla işlevsel bir bütünlük içinde yaşamalarını güçleştirmektedir.

Engelli bireylere ilişkin en önemli nokta, toplumda engellilikle ilgili "farkındalığın yaratılması" ve "anlaşılma" gereksinimlerinin karşılanmasıdır (Şahin, 2004, ss. 40-41).

Engellilerle ilgili konulara geleneksel yaklaşımlar, ya tıbbi yardım ya da hayırseverlik üzerine kurulmuş ve genellikle engelliliğin bireysel (biyo-medikal veya işlevsel) bir sorun olduğu varsayımından hareketle oluşturulmuştur. Engelli kişilere yönelik örgütler ise, engellilerin toplumda diğer bireylerle eşit haklara sahip ve bu haklar doğrultusunda toplumla bütünleşmek için mücadele eden kişiler olduğu gerçeğini çok az tanıyarak veya hiç tanımayarak ve onları pasif ve yardıma muhtaç bireyler şeklinde ayrı bir toplum olarak görüp, bu yönde engellilere özel hizmetler sunmuşlardır (Avrupa).

Son on-onbeş yıllık dönemde, dünya genelinde engelliler için faaliyet gösteren örgütler, engelli bireylerle ilgili konuları insan hakları yaklaşımı ile ele almışlar ve çevreci bir yaklaşım geliştirmişlerdir. Her iki yaklaşım da, engellilerin toplumla her yönden bütünleşebileceği bir toplum modeline dayanmaktadır. Engelli kişilerin haklarına ve toplumun tüm insanları içine alacak şekilde yeniden yapılandırılmasının gerekli olduğuna vurgu yapılmaktadır. Bu modellerde, kişilerin engellerinin değil, engelli kişileri dışlayan toplumsal örgütlenmenin engel oluşturduğu varsayılmaktadır (Avrupa). 
İnsan kaynakları bir ülkenin ilerlemesinde yaşamsal öneme sahip değerli ve geliştirilebilen kaynaklardır. İnsan bilgi birikiminin yapılanmasındaki en önemli süreç ise eğitimdir. Eğitim, bilimin gelişimini, fiziksel yeteneği ve sosyal farkındalığı harekete geçiren en önemli süreçtir (Butdisuwan, 1999).

Son yıllarda gelişmiş veya gelişmekte olan ülkeler, engel türü ne olursa olsun, ekonomik ve toplumsal yaşam içinde engelli tabanlı ayrımcılıkla mücadele etmek, gerek yasal gerekse sosyo-ekonomik düzenlemelerle toplumsal farkındalığı artırmak için engelli katılımlı eğitim, sosyal politikalar, ekonomi gibi modellerin oluşturulması gerektiğinde birleşmektedirler (Barnes, 1997). Son on-onbeş yıllık dönemde ise özellikle üniversiteler ve akademik kuruluşlar, engelliliğin toplumsal boyutları ve ayrımcılıkla mücadele konularında yoğunlaşmışlardır. Eğitimde fırsat eşitliğinin önemine vurgu yaparak 1990'lı yıllardan itibaren, tüm dünya ülkelerinde, üniversiteler, "engelli destek merkezleri," "engelli hizmet büroları", "engelli öğrenci birimleri” kurarak, bu alanda toplumsal duyarlılığa üniversite eğitimi kapsamında ilk adımları atmıştır (Akgül, ve Vercan, 2003, Aralık).

\section{Engelsiz Üniversite}

Gelişmiş ülkelerin hemen hemen tüm üniversiteleri, 1990'lı yıllardan itibaren engellilere sundukları olanaklar ile eğitim almalarını kolaylaştırdıklarını web siteleri aracılığı ile duyurmakta, engelli öğrenci adaylarını üniversite eğitimi konusunda cesaretlendirmektedirler. Bu üniversiteler engelli öğrenciler için yardımcı donanım ve bilgisayar teknolojilerini sağlayarak kendilerine güvenlerini ve bağımsızlıklarını kazandırmak yanında, üniversite yönetim hiyerarşisinde ilgili birim ve personelle "engelli destek merkezleri", "engelli öğrenci hizmetleri" kurarak, eğitimlerini kolaylaştırmayı da hedeflemişlerdir. Bu birimler tarafından sağlanan hizmetler, engelli öğrencilerin, diğer öğrencilerle akademik ortamda rekabet edebilmesine de olanak sağlamaktadır (Akgül, ve Vercan, 2003, Aralık). 
Aşağıda birkaç örneği verilen üniversitelerin engelli birimleri bu amaca yönelik olarak kurulmuştur:

- $\quad$ Boston Üniversitesi Engelli Hizmetleri Birimi (Boston University, Office of Disability Services) http://www.bu.edu/disability/index.html

- $\quad$ Harvard Üniversitesi Erişilebilir Eğitim Birimi (Harvard University, Accessible Education Office) http://aeo.fas.harvard.edu/faculty.html

- $\quad$ Pittsburgh Üniversitesi Engelli Hizmetleri ve Kaynakları (University of Pittsburgh, Disability Resources and Services) http://www.drs.pitt.edu

- $\quad$ Texas Tech Üniversitesi Engelli Öğrenci Hizmetleri (Texas Tech University, Student Disability Services) http://www.depts.ttu.edu/studentaffairs/sds/

- $\quad$ Oregon Üniversitesi, Engelli Hizmetleri (University of Oregon, Disability Services) http://ds.uoregon.edu/DS_Pages/DS_OverviewServices.html

Ülkemizde ise, 2005 yılında yürürlüğe giren, Özürlüler ve Bazı Kanun ve Kanun Hükmünde Kararnamelerde Değişiklik Yapılması Hakkında Kanun'un 15. Maddesinde (Kanun No: 5378 Kabul Tarihi: 01.07.2005), üniversitelerde, özürlü üniversite öğrencilerinin öğrenim hayatlarını kolaylaştırabilmek için araç-gereç temini, özel ders materyallerinin hazırlanması, özürlülere uygun eğitim, araştırma ve barındırma ortamlarının hazırlanmasının temini gibi konularda çalışma yapmak üzere Özürlüler Danışma ve Koordinasyon Merkezi kurulması, gereklilik olarak yer almıştır.

Anılan yasanın ardından, Yükseköğretim Kurumları Özürlüler Danışma ve Koordinasyon Yönetmeliği hazırlanmış, 20 Haziran 2006 tarih ve 26204 sayılı Resmi Gazete'de yayımlanarak yürürlüğe girmiştir. Yönetmeliğin amacl, “...yükseköğrenim gören özürlü öğrencilerin, öğrenim hayatlarını kolaylaştırabilmek için gerekli tedbirleri almak ve bu yönde düzenlemeler yapmak üzere, Yükseköğretim Kurulu Başkanlığı bünyesinde kurulan Özürlüler Danışma ve Koordinasyon Birimi ile Öğrenci Seçme ve Yerleştirme 
Merkezi ve üniversiteler bünyesinde oluşturulacak özürlülerle ilgili birimlerin çalışma usul ve esaslarını düzenlemektir". Yasanın 8. Maddesi "Yükseköğretim kurumları tarafından bir rektör yardımcısı sorumluluğunda, özürlü öğrencilerin akademik, idari, fiziksel, psikolojik, barınma ve sosyal alanlarla ilgili ihtiyaçlarını tespit etmek ve bu ihtiyaçların karşılanması için yapılması gerekenleri belirleyip, yapılacak çalışmaları planlamak, uygulamak, geliştirmek ve yapılan çalışmaların sonuçlarını değerlendirmek üzere, mediko-sosyal sağlık, kültür ve spor işleri daire başkanlığına bağlı özürlü öğrenciler birimi oluşturulur..." hükmü ile ilgilidir (Yükseköğretim, 2006).

Türkiye'de bu alandaki ilklerden biri, Orta Doğu Teknik Üniversitesinde 2004 yılında kurulan, ODTÜ Rektörlüğüne bağlı çalışan, "Engelsiz ODTÜ Koordinatörlüğü"dür (Engelsiz). Görevi, engelli öğrencilerle ilgili üniversitenin yasal işlemlerinin yürütülmesini sağlamaktır. Türkiye'de bu alanda kurulan ilk koordinatörlük olarak engelli öğrencilerin kendilerine güvenmelerine ve sosyalleşmelerine de yardımcı olan Engelsiz ODTÜ, 2006 yılında YÖK'ün engelli öğrencilerle ilgili yönetmeliğinin oluşturulmasına katkı sağlamış, diğer üniversitelerin engelli birimlerinin kurulmasına da önderlik etmiştir. Engelsiz ODTÜ Topluluğunun amaçları: ODTÜ'yü engelli öğrenciler için fiziksel ve eğitsel anlamda erişilebilir kılmak, diğer üniversitelerde de bu gibi çalışmaların yapılması için etkileşimde bulunmak, ODTÜ'de okuyan tüm engelli öğrencilere eğitsel, sosyal ve kültürel alanda destek olmak, gerek üniversitede gerek dışarıda, engellilere karşı var olan önyargıları yıkmak, toplumsal duyarlılıkları ve akademik nitelikli bilinci artırmaktır.

Hacettepe Üniversitesi Engelliler Araştırma ve Uygulama Merkezi (2008), 18 Ekim 2006 tarihinde kurulmuştur. Amacı, eğitimine devam eden ve çalışan tüm engelli Hacettepelilerin, bilgi ve becerilerini en etkin şekilde kullanarak eğitime, öğretime, sosyal yaşama ve kültürel alanlara eşit bir şekilde katılımlarına destek olmaktır. Bu amaca ulaşabilmek için belirlenen hedefler; üniversitedeki engelli bireylerin, ilk kayıt tarihinden başlayarak belirlenmesi, eğitim, öğretim ve kültürel etkinliklerden, bağımsız olarak yararlananabilmeleri ve çalışma yaşamına en yüksek verimlilikle katılabilmelerini engelleyen ortak kullanıma ait binaları (kafeterya, kütüphane, sağlık merkezleri, yurtlar, derslikler vb.), ulaşım, yollar ve 
park yerlerini, eğitim, öğretim ve sınav ortamlarını, sosyal, kültürel ve sportif etkinlik alanlarını engellilere uygun hale getirmek, engellerinden kaynaklanan sorunlarını (fiziksel ve psikolojik rehabilitasyon, sosyal hizmetler vb) danışabilecekleri birimlere yönlendirmek, toplum temelli rehabilitasyon olanaklarından faydalanmalarını sağlamaktır.

Ankara Üniversitesi Engelsiz Kampüs Projesi, Cebeci Kampüsünde, farklı fakültelerdeki engelli öğrencilerin ve çalışanların karşılaştıkları sorunlarla mücadele edebilmek için Kasım 2003'de başlatılmıştır. Bu çalışmaya bedensel, görme, işitme ve konuşma problemi olan bireylerin dâhil edilmesi planlanmıştır (Ankara).

Üniversitelerimizde, yalnızca yüksek öğrenim gören engelli öğrencilere değil, ülkemizdeki tüm engelli bireylere yönelik araştırma ve yayın yapmak, eğitim olanakları yaratmak ve desteklemek amacıyla kurulmuş, engelliler/özürlüler araştırma ve uygulama merkezleri de bulunmaktadır. Bunlar arasında başlıcaları şöyle sıralanabilir:

Anadolu Üniversitesi Engelliler Araştırma Enstitüsü, 1993 yılında kurulmuş ve 1994 yılında faaliyete geçmiştir. Enstitünün kuruluşundan bu yana yerine getirdiği işlevler dört ana grupta toplanabilir: Gelişimsel yetersizliği olan çocuklara yönelik araştırma ve yayın yapmak, ailelere, öğretmenlere/uzmanlara ve topluma; gelişimsel yetersizliği olan çocuklarla ilgili hizmet sunmak, gelişimsel yetersizliği olan bireylere hizmet sunmak, Anadolu Üniversitesinin diğer birimlerine öğretim/tez yönetimi desteğinde bulunmak. Enstitüdeki temel araştırma alanı, gelişimsel yetersizliği olan çocuklara etkili öğretim sunmadır. Bu temel alan içindeki belli başlı konu başlıkları ise; uygulamalı davranış analizi, doğrudan öğretim, yanlışsız öğretim ve otistik özellik gösteren çocukların eğitimidir (Anadolu).

İstanbul Üniversitesi Özürlüler Araştırma ve Uygulama Merkezi, Aralık 2003'de kurulmuştur. Özürlü bireyleri ulusal ekonomiye katkıda bulunmaları ve meslek edinmeleri için hazırlamaya yönelik eğitim, beceri ve deneyim kazanmalarını sağlamaya ilişkin destekleyici katkılarla, öncelikle özürlü üniversite öğrencilerine ve aynı zamanda toplumumuzdaki yüksek eğitim almak isteyen tüm özürlülerin 
sorunlarına çözüm getirmek için özürlüler alanında araştırma ve çalışmalar yapmaktadır (İstanbul).

Süleyman Demirel Üniversitesi Engelliler Araştırma ve Uygulama Merkezi ise,7 Mart 2005 yilında kurulmuştur. Merkezin misyonu; "engelli bireylerin yaşam kalitelerini artırmak, engelli bireylere ve ailelere ve sosyal çevrelerine her türlü yönlendirici, bilgilendirici ve eğitici danışmanlık hizmetleri, özel eğitim ve rehabilitasyon hizmetleri sunmak, engelli bireylere yönelik hizmet verebilecek alanında uzman personel açığını kapatmak ve bu amaçla eğitim faaliyetlerinde bulunmak, engelliliğe yönelik bilimsel araştırmalar yapmak, yurt içinde ve dışında engelli bireyler ile ilgili çalışmalar yapan her türlü kurum ve kuruluşla amaca dönük işbirliği yapmak" olarak belirlenmiştir (Süleyman).

Akdeniz Üniversitesi, Özel gereksinimli Bireyler Için Araştırma, Uygulama ve Eğitim Merkezi (2008), Aralık 2007'de kurulmuştur. Amacı; Antalya (Akdeniz) bölgesinde zihin ve hareket engelli çocuk sayısını saptamak, özür nedenleri, önlenmesi ve eğitim uygulamalarının etkileri üzerine araştırma yapmak, zihinsel engelli çocuklar için mental gelişim durumuna uygun bireysel ve grup eğitim olanakları yaratmak, beyin özürlü çocuklar için uygun egzersiz ve eğitim programları uygulamak, zihinsel ve fiziksel engelli çocuklar için müzik, resim, spor, el sanatları gibi etkinlikler düzenlemek ve bu etkinlikleri sergilemektir.

Yukarıda örnek verilenlerin yanı sıra diğer üniversitelerimiz de, Yükseköğretim Kurumları Özürlüler Danışma ve Koordinasyon Yönetmeliği uyarınca özürlü/engelli birimlerini kurmuştur:

- $\quad$ Abant İzzet Baysal Üniversitesi Engelsiz AiBÜ Koordinatörlüğü (http://www.ibu.edu.tr/analink/engelsiz.htm)

- Balıkesir Üniversitesi Özürlü Öğrenci Birimi (http://sks.balikesir.edu.tr/ozurlu.htm)

- Başkent Üniversitesi Özürlü Öğrenciler Birimi (http://www.baskent.edu.tr/idari/spor.php) 
- $\quad$ Bilkent Üniversitesi Engelli Öğrenciler Birimi (http://www.bilkent.edu.tr/bilkent-tr/admin-unit/dos/ssm/ engelli.html)

- $\quad$ Boğaziçi Üniversitesi Engelliler Komisyonu (http://www.boun.edu.tr/government/disabled_students_tur.html)

- $\quad$ Cumhuriyet Üniversitesi Engelli Öğrenci Birimi (http://www.cumhuriyet.edu.tr)

- $\quad$ Çukurova Üniversitesi Halil Avcı Duyma Engelli ve Özürlüleri Araştırma ve Uygulama Merkezi (http://rektorluk.cukurova.edu.tr/tr/merkez.asp)

- $\quad$ Fırat Üniversitesi Engelli Öğrenci Birimi (http://www.firat.edu.tr/\#)

- $\quad$ Kahramanmaraş Sütçü İmam Üniversitesi Özürlü Öğrenci Birimi (http://www.ksu.edu.tr/ozurluogrenci.php)

- $\quad$ Kocaeli Üniversitesi Engelliler Araştırma ve Uygulama Birimi (http://sksdb.kou.edu.tr/birim.doc)

- 19 Mayıs Üniversitesi Zihinsel Engelli Çocuklar Eğitim Uygulama ve Araştırma Merkezi (http://www2.omu.edu.tr/akademik_birimler/arastirma_uygulama.asp)

- $\quad$ Pamukkale Üniversitesi Özürlü Öğrenci Birimi (http://sks.pamukkale.edu.tr/tanitim.htm)

- $\quad$ Sabancı Üniversitesi Engelli Öğrenci Desteği (http://www.sabanci univ.edu/bagem/tr/?EngelliOgrenciDestegi/ EngelliOgrenciDestegi.html)

- $\quad$ Sakarya Üniversitesi Özürlü Öğrenci Birimi (http://www.sks.sakarya.edu.tr/index.php?pid=k_engelsiz1)

- $\quad$ Trakya Üniversitesi Armağan Dönertaş Engelli Çocuklar Eğitim, Rehabilitasyon ve Araştırma Merkezi (http://www.trakya.edu.tr/Merkezler/zihvehareket/index.htm)

- $\quad$ Uludağ Üniversitesi Özürlü Öğrenci Birimi (http://saglikkultur.uludag.edu.tr/015.htm) 
- $\quad$ Yüzüncü Yıl Üniversitesi Engelli Öğrenci Destek Birimi (http://sks.yyu.edu.tr/Bastan/engelli.htm)

Engelsiz bir üniversite, toplumdaki farkındalığı artırır. Farklı olanları içerebilen toplum, uygar bir toplumdur.

\section{Engelsiz Kütüphane ve Bilgi Hizmetlerinde Kütüphanecilerin Rolü}

Bireyin, toplum hayatının insanlara sunduğu olanak ve hizmetler-den yararlanabilmesi ve kendi hizmetini sunabilmesi, yani toplum hayatına tam katılabilmesi, ancak bireyin söz konusu faaliyetlerden ve hizmetlerden yararlanabilmesi ve bunlara ulaşabilmesi ile mümkündür. Bilgiye erişebilmek, bilgi ve iletişim teknolojilerinden yararlanabilmek de, toplumsal yaşama katılım yönüyle çok önemlidir. Bilgi çağının ve bilgi toplumunun gereklerinden biri olan bilgiye erişim, bireylerle ve toplumsal yaşam içindeki hizmetlere ulaşabilmekte etkili iletişim kurabilmeyi gerektirmektedir. Bu iletişim günlük konuşmalardan, bilgi kaynaklarına ulaşabilmekten bilgisayar kulanımına kadar geniş bir yelpazeyi kapsamaktadır

"Evrensellik, paylaşılabilirlik" ve "erişilebilirlik" bilginin en önemli özellikleridir. Bilgi bazlı, bilgisayar ve iletişim teknolojisi ve İnternet ağırlıklı yaşadığımız son yılların anahtar sözcüğü ise "bilgiye erişebilmek" tir. Bilgi çağı ve bilgi toplumunun gereklerinden en önemlisi, hangi ortamda bulunursa bulunsun bilgiye erişimi herkes için olanaklı kılmak, 20. yüzyılda olduğu gibi 21. yüzyılda da engellilerin, yaşadığımız bilgi bazlı sürecin dışında kalmaması gerektiğini düşünen bir toplumu yaratmaktır.

Ülkemiz tarafından 4 Nisan 2007'de imzalanan, toplam 50 mad-deden oluşan ve taraf olan devletlere, engellilere karşı ayrımcılığı ortadan kaldırmak ve onların yaşam standartlarını yükseltmek gibi yükümlülükler getiren 'Birleşmiş Milletler Engelli Hakları Sözleşmesi'nin "erişilebilirlik", "düşünce ve ifade özgürlüğü ve bilgiye erişim" ve "eğitim" maddeleri, çalışmamızla ilintili olması bakımından önemlidir.

\section{“...Madde 9- Erişebilirlik}

1. Taraf Devletler, engellilerin bağımsız yaşamalarının ve toplumun tüm alanlarına tam katıımının sağlanması ve engellilerin diğerleriyle eşit bir 
şekilde fiziksel çevreye, ulaşıma, bilgi ve iletişim teknolojisi ve sistemi dâhil bilgiye ve iletişime, hem kırsal hem de kentsel bölgelerde halka açık olan veya halka sunulan diğer tesislere ve hizmetlere erişiminin sağlanması için uygun tedbirleri almalıdır. Bu tedbirler erişime yönelik engellerin tespitini ve ortadan kaldırımasını da içermelidir. Bu tedbirler aşağıda belirtilen yerler ve hizmetler bakımından da geçerlidir:

(b) Elektronik hizmetler ve acil hizmetler de dâhil olmak üzere, bilgi ve iletişim araçları ve diğer hizmetler

2. Taraf Devletler, ayrıca aşağıdakileri gerçekleştirmek için uygun tedbirler almalıdır:

(a) Kamuya açık olan veya kamuya sunulan tesis ve hizmetlere erişime ilişkin asgari standart ve kılavuz ilkeler geliştirmek, ilan etmek ve bunların uygulanmasını izlemek;

(b) Kamuya açık tesisleri işleten veya kamuya hizmet sunan özel teşebbüslerin, engellilerin erişebilirliğini her açıdan dikkate almalarını sağlamak;

(c) Engellilerin karşılaştığı erişim sorunlarına yönelik olarak ilgili kişileri eğitmek;

(f) Engellilerin bilgiye erişimini sağlamak için, onlara uygun yollarla yardım ve destek sunulmasını teşvik etmek;

(g) Engellilerin internet dâhil olmak üzere yeni bilgi ve iletişim teknolojilerine ve sistemlerine erişimini teşvik etmek;

(h) Erişilebilir bilgi ve iletişim teknolojileri ve sistemlerinin tasarımını, geliştirilmesini ve dağıtılmasını ilk aşamadan başlayarak teşvik etmek ve böylelikle bu teknoloji ve sistemlere asgari maliyetle ulaşılabilmesini sağlamak.

\section{Madde 21- Düşünce ve Iffade Özgürlüğü ve Bilgiye Erişim}

Taraf Devletler, engellilerin tüm iletişim araçlarını tercihlerine bağlı olarak kullanabilmesi, bilgi ve fikirleri araştırma, alma ve verme özgürlüğü dâhil düşünce ve ifade özgürlüğünden diğerleriyle eşit bir şekilde 
yararlanabilmesi için uygun tüm tedbirleri almalıdır. Bu tedbirler aşağıdakileri içermelidir:

(a) Kamuya sunulması amaçlanan bilginin engellilerin erişebileceği biçimlerde ve farklı engelli gruplarına uygun teknolojilerle, güncel olarak ve ek bir bedel alınmaksızın sunulması;

(c) Kamuya açık hizmet sunan özel kuruluşların, Internet dâhil olmak üzere, engellilerin erişilebileceği ve kullanılabileceği biçimde bilgi ve hizmet sunmalarının teşvik edilmesi;

(d) Internet aracılığıyla bilgi sunanlar dâhil olmak üzere, kitle iletişim hizmeti sunan kurumların, hizmetlerini engellilerin erişebileceği şekillerde sunmalarını teşvik etmek.

(e) Işaret dilinin kullanılmasının tanınması ve teşvik edilmesi.

\section{Madde 24- Eğitim}

1. Taraf Devletler, engellilerin eğitim hakkını tanırlar. Taraf Devletler, bu hakkın fırsat eşitliği temelinde ve ayrımcılık yapılmaksızın sağlanması için, eğitim sisteminin her seviyede engellileri de içine almasını ve ömür boyu öğrenim imkânı sağlamalıdır.

4. Taraf Devletler, bu hakkın hayata geçmesini sağlamak için, engelli olanlar dâhil olmak üzere, işaret dilini ve Braille alfabesini bilen öğretmenlerin işe alınması ve eğitimin her düzeyinde çalışan uzmanların ve personelin eğitilmesi için uygun tedbirler almalıdır. Söz konusu eğitim, engelliliğe ilişkin bilincin yükseltilmesini, uygun alternatif iletişim araç ve biçimlerinin, destekleyici eğitim tekniklerinin ve materyallerinin kullanılmasını içermelidir" (Birleşmiş).

Birleşmiş Milletler Engelli Hakları Sözleşmesi'nin, özellikle 9, 21 ve 24. maddelerinde gözetilen çabalara, bilgi hizmeti sunan kütüphanecileri yetiştiren bölümlerin de katılması gerekmektedir. Amaç, bireylerinin eşit koşullarda birlikte çalışıp, yan yana yaşayarak oluşturulacak bir toplumu, bir dünyayı gerçekleştirmekse, çalışmaların, özellikle engelli bireylere sunulacak hizmetler, sistemler, 
planlar bağlamında bilgilenmek, bilinçlenmek ve duyarlıı̆ı artırmak yönünde de yoğunlaştırılması gerekmektedir.

Etkili, etkin bilgi hizmeti kütüphaneler/bilgi merkezleri ile verilebilir ve ancak kütüphanecilerle başarılabilir. Özel gereksinimlere yanıt verecek eğitim, üniversitelerin kütüphanecilik bölümlerinde gerçekleştirilebilir (Norton, 1992).

Günümüzde yaşanılan bilgi çağında entelektüel sermayenin önemi ve kütüphanelerin toplumsal ve ekonomik koşulları dönüştürmedeki rolü, gerek gelişmiş gerekse gelişmekte olan ülkelerde kabul edilmektedir. Devlet ve hükümet başkanları için hazırlanan “Japonya'daki G8 Zirvesi'nin Küresel Enformasyon Toplumu üzerine Okinawa Bildirgesi" başlıklı raporda şöyle denilmektedir: "Bilgi teknolojileri güdümlü ekonomik ve toplumsal dönüşümün özü, bilgi ve fikirlerin birey ve toplumlar tarafından kullanılmasına yardım etme gücüdür" (Okinawa, 2000; Carlos, 2005). Bu bağlamda, özellikle engellilerin kendilerini geliştirme fırsatının yaratılması, kendilerine güvenin kazandırılması önemlidir.

Gereksinim duyan kişiye, gereksinim duyduğu bilgiyi, gereksinim duyduğu kapsamda ve biçimde, hızlı, ekonomik ve etkin yollarla sağlamayı amaçlayan kütüphane ve bilgi hizmetleri, bireysel ve toplumsal bilgi ihtiyacının ürünü olarak ortaya çıkmıştır. Hizmet verilen toplumsal, bireysel ve kurumsal yapı içinde bilgi gereksinimlerinin doğru algılanması ve yönlendirilmesi, hizmetlerde etkililik ve verimliliğin sağlanmasında belirleyici öneme sahiptir.

Demografik yapıdaki değişiklikler ve belirli grupların belirli gereksinimleri, kütüphanelerin / bilgi merkezlerinin hizmetlerini genişletmesini ve yeni hizmet alanları açmasını gerektirmektedir. Toplumlardaki eşitsizliği ortadan tamamıyla kaldırmak mümkün olamayacağı için, toplumsal kuruluşlar, eşitsizliği azaltma sorumluluğuna sahip olmalıdır. Bu bağlamda kütüphanelerin, toplum içindeki rolünü yeniden belirlemesi ve işlevlerini yeniden gözden geçirmesi, diğer taraftan sosyal bir kurum olarak misyonunu güçlendirmesi gerekmektedir (Ershova ve Hohlov, 2000). Bireysel ve toplumsal gelişmeler ve gereksinimler doğrultusunda hizmet stratejilerini saptayarak bilgi hizmetlerini geliştirme sorumluluğu, doğrudan kütüphanecilerindir. 


\section{Engellilere Sunulacak Kütüphane I Bilgi Hizmetlerinde "Kütüphanecilik Eğitimi” Araştırmaları}

Bireysel ve toplumsal gereksinimler kapsamında, engelli bireylere yönelik kütüphanecilik hizmetleri ile ilgili literatürün büyük bölümü-nün üç dönemde ortaya çıktığı görülmektedir: Rehabilitasyon Yasasının çıkarılmasını izleyen dönem (1970'lerin sonu ile 1980'lerin başı); Özürlü Amerikalılar Yasasının çıkarılmasını izleyen dönem (1990'ların ortası) ve Bölüm 508'in* yürürlüğe girmesini izleyen dönem (1990'ların sonundan günümüze). Bu literatürün çok küçük bir bölümü, kütüphanecilerin mesleklerine başlamadan önce engellilere yönelik hizmetler konusunda nasıl eğitilebilecekleriyle ilgilidir. Ancak, engellilere yönelik hizmetlerin kütüphanecilik ve bilgi biliminin mesleki duyarlıı̆ına daha fazla dâhil edilmesiyle birlikte bu durum da değişmeye başlamıştır (Carlos, 2005).

Engellilere yönelik hizmetlerde eğitimle ilgili kütüphanecilik ve bilgi bilimi programları bağlantılı ilk araştırma, 1976 yılında Kongre Kütüphanesi Görme ve Fiziksel Engelliler Bölümü danışma kütüphanecisi Merrilyn Gibson tarafından yapılmıştır. Gibson, bu araştırmasından elde ettiği sonuçları, "Preparing Librarians to Serve Handicapped Individuals" (1977) başlıklı makalesinde aktarmaktadır. Araştırma, Rehabilitasyon Yasası'nın çıkarılmasının ardından Bölüme ulaşan çok sayıda soruya yanıt niteliğindedir. Yöneltilen soruların büyük bölümü, kütüphanecilerin engellilere hizmetle ilgili eğitimi nerelerde alabileceklerine ilişkindir. Araştırmanın sonuçları ise umut verici değildir. Kütüphanecilik eğitimi veren okulların \% 73'ü engellilere yönelik hizmetlerle ilgili herhangi bir derse yer vermemektedir ve bu alanda eğitime ilişkin herhangi bir planları da yoktur (Carlos, 2005).

Engellilerle ilgili literatürdeki önemli çalışmalardan biri, IFLA'nın 1993 Barcelona Genel Konferansı Çalıştayıdır. Körler, Engellilere Kütüphane Hizmeti ve Eğitim başııkları altında üç bölüm olarak düzenlenen Çalıştay, "Interaction Between Library Schools and

\footnotetext{
* Bölüm 508, 1973 yılında çıkarılan Rehabilitasyon Yasasının bir bölümüdür ve federal hükümet tarafından geliştirilen, dağıtılan ve kullanılan elektronik ve bilişim teknolojilerinin engelli kişilerce erişilebilir olmasını zorunlu kılar. Bu bölümde belirtilen standartlar yasal yönden erişilebilirliğin nasıl sağlanacağını ayrıntıı olarak açıklamaktadır.(http://www.accessboard.gov/sec508/FAQ.htm\#1)
} 
Specialized Library Services" başlığını taşımaktadır. Çalıştayın amacı, kütüphanecilik bölümleri eğitim kadrosunun engelli bireylerin gereksinimlerine duyarlılıklarını artırmaktır. Çalıştayın sonunda, beş temel çözümün ders programları kapsamında başarılabileceği görüşüne varılmıştır. Bunlar:

1. Eğitimciler, bu alanla ilişkili olarak eğitilmelidir (eğitimcilerin eğitimi).

2. Hizmet verilecek engelli kullanıcıların tanımlanmalıdır.

3. Engelli bireylerin gereksinimleri konusunda kütüphanecilik öğrencilerinin duyarlılığını artırmak amacıyla ders programına zorunlu dersler konulmalıdır.

4. Kütüphanecilik bölümlerinin ders programındaki birçok dersin içeriğine engelliler konusu dâhil edilmelidir.

5. Ek olarak, ders programlarına psikoloji, hukuk, sosyoloji dersleri de konulmalıdır (Galler, 1997, ss. 365-366)

IFLA Çalıştayından sonra, 1994 yılında, Anne Galler (1997), Kütüphanecilik Bölümleri/Okulları kapsamında uluslararası bir çalışma gerçekleştirmiş ve IFLA Journa/'da yayınlanmıştır. Galler'in altı sorudan oluşan anket çalışması, tüm dünyadaki kütüphane, arşiv ve bilgi bilimi alanında eğitim veren 430 okula/bölüme e-posta ile dağıtılmış, yanıt veren 88 bölüm değerlendirmeye alınmıştır. Anket sonuçlarına göre:

- Kütüphanecilik bölümlerinin ders programlarında, toplumun tüm bireylerine bilgi hizmeti verme ilkelerinin içerildiği en az bir dersin bulunduğu (66 bölüm);

- Ders konuları arasında doğrudan engellileri ilgilendiren derslerin bulunmadığı (70 bölüm), birkaç bölümde "derme yönetimi”, "bilgi danışmanlığı", "bilgi toplumu”, "özel bilgi gereksinimli bireylere kütüphane hizmeti” gibi derslerde engellilere yer verildiği, duyarlılığın artırılmasına yönelik konuların ise "halk kütüphaneleri hizmetleri” başlığı altında verildiği;

- $\quad$ Ders programları içerisinde engel kategorilerinden çoğunlukla görme ve işitme engeli olanlara ilişkin konuların yer aldığı; 
- Fiziksel erişilebilirlik, kütüphane tasarımı gibi konulara, genellikle "yönetim" derslerinde değinildiği (42 bölüm);

- $\quad$ Sadece 12 bölümde engellilere yönelik seminer derslerinin bulunduğu, lisans, yüksek lisans ve doktora düzeylerinde engellilere ilişkin tezlerin yapılmış olduğu (Doktora 22, Yüksek Lisans 51, Lisans 5);

- "Kütüphane otomasyonu" dersinde uyarlanmış teknolojilere, "kataloglama" derslerinde Braille gibi özel formatlara ise yer verilmediği (66 bölüm) saptanmıştır.

Galler (1997, ss. 369-370)'in çalışması, anketin dağıtııdığı öğretim üyelerinin ve kütüphanecilerinin, engellilerin sorunlarına duyarlııklarını artırmış ve ders programlarını engelli odaklı olarak geliştirmelerinin gerekli olduğuna vurgu yapmıştır.

Engellilere yönelik önemli diğer bir çalışma ise, South Carolina Üniversitesi Kütüphane ve Bilgi Bilimleri Fakültesi Profesörlerinden Linda Lucas Walling'e ait kütüphanecilik ve bilgi bilimi bölümlerinin programlarında engellilere yönelik hizmetler konusuna yer verilmesi ile ilgili araştırmasıdır. Walling (2004, ss. 137-138,141), çalışmasında kütüphanecilik ve bilgi bilimi okullarını/bölümlerinin, öğrencilerini, "Engelli Amerikalılar Yasası (ADA), engellilere yönelik hizmetler, yeterlilikler ve uyarlanabilir teknolojiler" gibi alanlarda eğitip eğitmediklerini saptamaya yönelik olarak, ABD ve Kanada'da ALA akreditasyonuna sahip 55 kütüphanecilik okulunun başkanlarına altı sorudan oluşan bir anket göndermiş ve bunların (ABD'den otuz, Kanada'dan altı okul) 36'sından yanıt almıştır. Ankete yanıt veren okul başkanlarının tamamı, öğrencilerine Engelli Amerikalılar Yasasını veya Kanada'da eşdeğer yasal düzenlemeyi öğreten programlar olduğunu belirtirken, \% 91'i de programlarında engellilere yönelik hizmetlerle ilgili bilgilerin de yer aldığını, \% 73'ü de uyarlanmış teknoloji derslerinin bulunduğunu belirtmiştir.

Bir başka çalışma, Deborah J. Carlos tarafından 2005 yılında gerçekleştiren "Instruction in Disability Services and Adaptive Technology in Schools of Library and Information Science: A Survey of the Curriculum" başlıklı yüksek lisans tezidir. ABD'deki ALA akreditasyonuna sahip dokuz üniversitenin (Dominican University, 
Indiana University, Emporia State University, Louisiana State University, San Jose State University, State University of New York Albany, University of Kentucky, University of Maryland, Wayne State University) kütüphanecilik bölümlerinin 2004-2005 akademik yılı ders programlarını incelemiş ve sadece üç bölümde doğrudan engellilere yönelik derslerin bulunduğunu saptamıştır. Bunlardan bazıları Dominican University'de, Engelli Amerikalılar Yasası'na uygun olarak kütüphane planlamasını içeren "Kütüphanelerin Planlanması ve Donanımı" dersi; Indiana University'de, engelliler için erişilebilir kütüphane sistemleri oluşturma içerikli "Kütüphane Otomasyonu" dersi ile engelli kullanıcılara yönelik program geliştirme ve planlama konusunun işlendiği "Kütüphane Hizmetleri Yönetimi ve Programları" dersi; State University of New York Albany'de, "Engelliler ve Bilgisayar Kullanımı" dersidir.

Carlos (2005), araştırması esnasında diğer bölümlerinin tümünün, engellilere sunulacak hizmetler kapsamında en az bir zorunlu dersi ders programlarına ekleyeceklerini ifade ettiklerini belirtmiştir.

\section{Kütüphanecilik / Bilgi ve Belge Yönetimi Ders Programlarına Dünyadan Örnekler}

Çalışmamızın bu kesimine örnek oluşturabilmesi açısından, çeşitli üniversitelerin kütüphanecilik/bilgi bilimi okulları/bölümlerinin web sayfaları, ders programları ve içerikleri araştırılmıştır. Çok az sayıda kütüphanecilik bölümünün, ders programlarında doğrudan engellilere yönelik derslere yer verdiği, büyük çoğunluğunun engelli konusunu programlarındaki derslerle içselleştirdiği saptanmıştır. Örneğin;

The University of North Carolina at Greensboro, Department of Library and Information Studies: "Farklı Kullanıcı Gruplarına Verilen Kütüphane Hizmetleri” dersinin içeriğinde, engellilere verilecek kütüphane hizmetinde derme özelliği ve personel niteliği yer almaktadır (http://www.uncg.edu/lis/courses/658.html).

Clarion University of Pennsylvania, Library Science: "Çok Kültürlü Kütüphane Hizmetleri ve Kaynakları" dersinde farklı etnik, ırk, cinsiyet veya engele sahip kütüphane kullanıcılarına yönelik derme ve hizmet geliştirme konuları yer almaktadır (http://www.clarion.edu/edu-humn/syllabi/courses.htm). 
University of Illinois at Urbana-Champaign, Graduate School of Library and Information Science: "Web Kaynaklarına Evrensel Erişilebilirlik" dersinde öğrenciler, salt engellilerin değil, tüm birey-lerin web kaynaklarına kolay erişebilmelerini amaçlayan bir içerikte eğitilmekte, ayrıca, web erişilebilirlik sorunlarına değinilirken, öğrenciler, web kaynaklarının erişilebilirliğini değerlendirmektedirler. (http://www.lis.uiuc.edu/oc/courses/catalog/catalog. html)

University of Hawaii at Manoa, Library and Information Science: Yüksek lisans programında seçmeli dersler kapsamında, "Kütüphane Hizmetleri" dersinde, halk ve okul kütüphanelerinde hizmetlerin planlanması, programlanması ve geliştirilmesi, engellilere ve diğer özel gruplara verilecek hizmetler kapsamında son gelişmeler, ağ kurulumları, halkla ilişkiler, sosyal yardım konuları yer almaktadır (http://www.catalog.hawaii.edu/courses/departments/lis.htm)

University of North Carolina at Chapel Hill, School of Information and Library Science: Yüksek lisans programını, çeşitli kurumlar (akademik, halk, okul, özel vb) ve gruplara (çocuklar, yetişkinler, engelliler vb) ilişkin, derme geliştirme, yönetim, bilgi depolama ve erişim konularını kapsayacak şekilde oluşturmuştur (http://sils.unc.edu/news/publications/ fliers/MSLS_sept04.pdf)

The Florida State University, College of Information: Doktora ders programında, "Kütüphanecilik/Bilgi Çalışmalarında Sorunlar" adlı derste, kütüphanecilik/bilgi çalışmalarının çeşitli alanlarındaki (kataloglama ve sınıflama, engellilere, çocuk ve gençlere verilen hizmetler, akademik, halk, okul ve özel kütüphaneler, yönetim, bilgi bilim vb) gelişmeler içinde çeşitli sorunlar irdelenmektedir (http://ci.fsu.edu/graduate/courses/phd.asp).

\section{Türkiye'de Bilgi ve Belge Yönetimi Bölümleri Ders Programlarında "Engellilik" ve "Engelliler"}

2007-2008 akademik yılı içinde Ankara, Hacettepe, İstanbul, Marmara ve Başkent Üniversitesi Bilgi ve Belge Yönetimi (BBY) Bölümlerinin lisans ve lisansüstü ders programları ve içerikleri incelenerek engellilere yönelik derslerin varlığı saptanmaya çalışımışıır. Ayrıca anılan bölümlerin öğretim üyelerine e-posta yoluyla, doğrudan engellilere yönelik derslerinin bulunup bulunmadığı, 
ayrıca ders konuları arasında öğrencilere bu gruba ilişkin bilgi veriliyorsa, hangi başlıklar altında ne tür bilgilerin verildiği sorulmuştur. Ankara, Hacettepe, İstanbul ve Marmara Üniversitesi BBY Bölümleri öğretim üyelerinin tamamı yanıt vermiştir. Başkent Üniversitesi BBY Bölümünden, ders programı kapsamında engellileri içeren dersler bulunmadığına dair geribildirim alınmıştır.

Atatürk Üniversitesi BBY Bölümü lisans ve/veya lisansüstü programa henüz başlamadığı için kapsam dışında bırakılmıştır. Elde edilen bilgilere ülkemizdeki durum şöyledir:

\section{Ankara Üniversitesi, Dil ve Tarih-Coğrafya Fakültesi, Bilgi ve Belge Yönetimi Bölümü}

\section{Lisans ders programında;}

"Sistem Analizi" dersinde kütüphaneyi oluşturan beş temel bileşenden özellikle derme, bina ve kullanıcı başlıklarında engelliler konusu irdelenmekte, bu grubun kütüphane hizmetlerine erişebilmeleri kapsamında, bina özellikleri, kütüphane tanıtım ve eğitim programları, engellilere yönelik olarak gerçekleştirilebilecek sanatsal, kültürel ve bilimsel faaliyetler konuları tartışılmaktadır.

"Bilgi Hizmetleri" ile "Kullanıcı Grupları ve Eğitimi” derslerinde, engelli kullanıcı grupları tanımlanmakta, engellilere yönelik geleneksel ve web tabanlı bilgi hizmetlerine örneklerle değinilmektedir.

“Derme Geliştirme” dersinde, özellikle halk kütüphanelerinde kullanıcı odaklı materyal seçimi ve engelliler için e-kitap kullanımına yönelik olarak sağlama politikası oluşturulması konuları işlenmektedir.

"Halk ve Okul Kütüphaneleri” dersinde halk kütüphanelerinde engellilere, özellikle körlere yönelik hizmetlere değinilmektedir.

"Araştırma Kütüphaneleri" dersi kapsamında milli kütüphanelerde ve özellikle ülkemiz Milli Kütüphanesinde körlere ilişkin hizmetler anlatılmaktadır.

"Bilgi ve Belge Bilimine Giriş" dersinde, bilgi merkezleri kapsamında engellilere yönelik kurulmuş kütüphaneler ve hizmetleri tanıtılmaktadır. 
"Etik ve Mesleki Sorumluluk" dersinde, toplumsal, ekonomik ve kültürel değişimlere duyarlı olmayı sağlayarak sorunları doğru analiz edebilme ve bu doğrultuda mesleki perspektif geliştirme, bilgi merkezi türlerine göre kullanıcı gruplarına yönelik hizmetler konusunda kuramsal bilgi alt yapısını oluşturma konuları işlenmekte, kütüphaneci-toplum-birey üçgeni içinde, engelliler için de sözü edilen başlıklarda, mesleki sorumluluğun ve duyarlılığın artırılmasına çalışılmaktadır.

"Bilgi Toplumu" dersinin içeriğinde, "herkes için bilgi toplumu" projeleri, (e-Europa girişimi, engelsiz dünya, engelsiz Avrupa, engelsiz Türkiye vb.) engellilere yönelik olarak irdelenmektedir.

\section{Doktora ders programında;}

"Özel Kullanıcı Gruplarına Yönelik Bilgi Hizmetleri” dersinde, engellilere yönelik geleneksel ve web tabanlı bilgi hizmetlerine yer verilmektedir.

"Kütüphane Binaları" dersin içeriğinde, kütüphane binasının planlanmasında engelli bireylerin de rahatlıkla ulaşabileceği ve kullanabileceği tasarımlara değinilmektedir.

"Engelli Kullanıcıların Bilgiye Erişimi” adı ile Doktora programında verilen Seminer dersinde, engellilik tanımları, engel grupları, engellilik nedenleri, $A B D, A B$ ve Türkiye'de engellilere yönelik yasal düzenlemeler, engellilerin toplumla bütünleşmesinde iletişim ve bilgiye erişim, erişilebilirlik konusunda yapılan çalışmalar, geliştirilen öneriler ve çözümler yer almaktadır.

Ayrıca her yıl 2-3 öğrenci, engelliler ve engelliliği konu edinen lisans tezi yapmaktadır.

\section{Hacettepe Üniversitesi, Edebiyat Fakültesi, Bilgi ve Belge Yönetimi Bölümü}

\section{Lisans ders programında,}

"Bilgi Sistemleri Tasarımı" dersinde erişilebilirlik konusu kapsamında engellilere yönelik web sitesi tasarımına değinilmektedir.

"Bilgi Merkezleri" ile "Bilgi Merkezleri Kurma ve Geliştirme" derslerinde özellikle görme ve işitme engellilere yönelik hizmetler ile 
Türkiye'deki ve dünyadaki örnekler tanıtılmaktadır. Konuya özel ilgi duyan örgencilerle Türkiye'de, ilgili merkezlerde, derneklerde, okullarda, Milli Kütüphane'de, neler yapılabileceği tartışılmaktadır.

"Bilgi Gereksinimi ve Kullanıcı Grupları" dersinde tüm kullanıcı grupları ele alınırken, engellilere, özellikle görme engellilere ilişkin konulara yer verilmektedir.

"Halk Kütüphaneleri" dersi kapsamında, 'halk kütüphaneleri hizmetleri' başlığı altında engelli kullanıcılara verilecek hizmetler tartışılmaktadır.

"Araştırma Kütüphaneleri” dersinde, Milli Kütüphaneler konusu irdelenirken, yurt dışı ülkelerde ve Milli Kütüphanemizde engellilere yönelik koleksiyonlara ilişkin bilgiler verilmektedir.

"Bilgi Merkezlerinin Yönetimi" dersi içeriğinde engellilerin bilgi merkezlerini kullanım koşulları ve sorunları tartışılmakta, genelde engellilerin bilgi merkezlerine erişimi, bilgi merkezlerinin iç mekân tasarımı, kaynakların kullanım olanaklarının geliştirilmesi, kütüphaneci - kullanıcı iletişiminin etkinleştirilmesi vb. konular işlenmektedir.

"Bilgi Merkezleri Mevzuatı" adlı derste, mevzuat uygulamaları kapsamında engellilere yönelik düzenlemeler içeren hükümlere değinilmektedir.

Son sınıftaki "Seminer" dersinde verilen araştırma konuları arasında engelliler hakkında çalışmak isteyen yılda 2-3 öğrenci bulunmaktadır.

\section{İstanbul Üniversitesi, Edebiyat Fakültesi, Bilgi ve Belge Yönetimi Bölümü}

\section{Lisans ders programında;}

"Bilgi Merkezi Kurma ve Geliştirme" adlı derste engellilik konusu, özellikle donanım ve yazılımlar açısından irdelenmekte, örnek olarak İstanbul Üniversitesi Merkez Kütüphanesi ve Edebiyat Fakültesi için hazırlanan projelere değinilmektedir.

"Derme Geliştirme" dersinde, görme engellilere yönelik dermenin özellikleri incelenmektedir. 
"Bilgi Hizmetlerinin Pazarlanması" dersinde kullanıcı grupları arasında, engellilerin gereksinimlerinin belirlenmesi ve karşılanmasına yönelik çalışmalar aktarılmakta, Boğaziçi Üniversitesi ve Beyazıt Devlet Kütüphanesinden örnekler verilmektedir.

\section{Marmara Üniversitesi, Fen-Edebiyat Fakültesi, Bilgi ve Belge Yönetimi Bölümü}

\section{Lisans ders programında;}

"Bilgi ve Belge Merkezleri" dersinde, tüm bilgi merkezi türlerinde, özellikle halk ve çocuk kütüphanelerinde engelli kullanıcılar konusu ele alınmaktadır.

"Restorasyon" dersinde, koruma planı hazırlanması ve personel eğitimi (personelin koruma planı içinde acil durum ya da felaket planlaması programı yapılırken sağlık sorunluların ve engellilerin dikkate alınması gibi) konusunda engelliler ve engellilik tartışılmaktadır.

"Kitap Yayıncılı̆̆ı" dersinde engelliler için kitap yayıncılığı konusu (görme engelliler için büyük punto yayın vb) örneklerle ele alınmaktadır.

Çalışmamızda, özellikle, ülkemizdeki BBY bölümleri öğretim üyelerinden e-posta ile alınan yanıtların değerlendirilmesi, iki önemli durumu belirginleştirmiştir:

1. Engelliler konusu, ders programlarındaki mevcut derslerle büyük oranda içselleştirilmiştir;

2. BBY bölümleri öğretim üyelerinin "engelli" bireylere sunulan ve/veya sunulacak kütüphane ve bilgi hizmetleri konusunda farkındalık ve duyarlılıkları sevindirici ve umut vericidir.

Ancak, ülkemiz nüfusunun \% 12.29'unu engelli bireylerin oluşturduğu ve bu oranın, nüfus çoğaldıkça ve yaşlandıkça, giderek artacağı göz önüne alındığında, engelli bireylere verilecek bilgi hizmetleri kapsamında gerçekleştirilen çalışmaların yeterli olduğunu söylemek güçtür.

BBY eğitiminin engellilere yönelik temel hedefleri ne olmalıdır sorusuna yanıtlarının verilmesi gerekmektedir. Örneğin; 
BBY bölümleri, öğrencilerini, öncelikle, tıbbi model (Bu insanların neyi eksik) yerine sosyal modeli (Bu insanları hizmetlerimizden yararlanmaktan alıkoyan engelleri nası ortadan kaldırırız) anlayışını benimseyecek biçimde eğitmelidirler (Kavanagh ve Sköld, 2005)..

Derslerde öğrenilen kuramsal bilgilerin uygulama ile içselleştirilmesi önemlidir. Bu, belirli bir topluluk içinde görev yapan öğrencilerin hem bu topluluğun üyelerini hem de kendilerini zenginleştirmelerini sağlar. 20. yüzyılın başlarında, William James ve John Dewey gibi bilim insanları da, eğitimde ve toplum hizmetlerinde kuram ve pratiğin kaynaştırımasının önemini vurgulamıştır (Carlos, 2005). Hizmet öğrenimi*, kütüphanecilik ve bilgi bilimi eğitimi ders programlarına son yıllarda dâhil edilmiştir. Ve burada engellilere yönelik hizmet eğitimini güçlendirebilecek bir kavram söz konusudur. Becker (2000) ile Yontz ve de la Pena McCook (2009)'un çalışmaları, hizmet öğrenimi kavramını -topluluk ortamlarına aktif katılım yoluyla eğitimderinlemesine ele almaktadır. Becker, ABD'de hizmet öğre-niminin tarihsel köklerini ve bunun ardındaki kuramsal çerçeveyi tartışırken, Yontz ve McCook da hizmet öğrenimi programlarına gerçek yaşamdan örnekler vermekte ve Florida'nın Clearwater kentinde başlatılan engellilikle ilgili bir projeden söz etmektedir. Güney Florida Üniversitesi Kütüphanecilik Bölümünden bir öğrenci, Pinalla İlçesi Konuşan Kitap Kütüphanesi (Kongre Kütüphanesi Ulusal Kütüphanecilik Hizmetleri tarafından Görme ve Fiziksel Özürlüler için düzenlenen Konuşan Kitap kütüphanelerinden biri) için bir dostluk grubu oluşturmuştur. Bu projeyle öğrenci, organizasyon, halkla ilişkiler ve kütüphane hizmetleri alanlarında zengin deneyimler kazanırken, yerel topluluk da engelli bireylere kaynak ve yardım sunabilecek yeni bir gruba sahip olmuştur. (Carlos, 2005).

Özel kullanıcı gruplarına yönelik örneğin; danışma ve ödünç verme hizmeti gibi kütüphaneci-kullanıcı etkileşiminin irdelendiği

* Toplumsal hizmetle bağlantılı, kurumsallaşmış bir hizmet içinde çalışmayı öğreten, önemli değerler ve konularda farkındalık yaratma amacını güden öğretme ve öğrenme biçimidir. Toplumsal Katılım Programları, okullarda ve kuruluşlarda etkili bir araç olarak kullanılmaktadır. Hizmet öğrenimi, genellikle üç aşamalı bir süreç olarak kabul edilir; (okullarda) öğrencilerin önerilen hizmet programı dönemi ve amaçlarını taslak olarak sunmaları, hizmetin yerine getirilmesi, deneyimlerin aktarılması (http://www.nyc.gov.sg/sl/index.htm; http://www.r10.net/insan-kaynaklari.html). 
derslerde, öğrencilere engelli kişilerle iletişimde gözetilecek kurallar ve iletişim konularıyla ilgili bilgiler yer almalıdır. Artık giderek daha fazla sayıda engelli birey, toplumsal ve mesleki alanlarda başkalarıyla etkileşime girmektedir. Engelli kimi bireylerin iletişim kurma güçlükleri vardır ve bu güçlükler gerek kendilerinde gerekse iletişim kurmaya çalıştıkları kişilerde sorun oluşturabilmektedir. Engelli insanlarla engelli olmayanlar arasındaki etkileşimin verimli gerçekleştirilmesini sağlamak üzere geliştirilmiş ve yaygın olarak kabul edilmiş birtakım kurallar vardır. Bu kurallara salt kütüphanecilerin değil, toplumun tüm bireylerinin engellilerle iletişimde özen göstermesi önemlidir. Örneğin;

- Doğrudan engelli kişiye hitap edin; ona yardım için yanında bulunabilecek herhangi bir yardımcıya veya başka birine değil.

- Bağırmayın veya konuşmanızı abartılı biçimde yavaşlatmayın. Karşınızdaki sizi anlamamışsa mümkün olduğu kadar net biçimde yeniden anlatın. Bu da işe yaramıyorsa yazı yolunu deneyin.

- $\quad$ Engelli yetişkinlere sanki bir çocukla konuşuyormuşsunuz gibi hitap etmeyin. Örneğin başlarını okşama gibi güçsüzlük ima edecek hareketlerle bulunmayın.

- Karşınızdaki kişinin ne dediğini anlayamıyorsanız sabırlı olun ve tekrarlamasını bekleyin. Araya girip onun sözlerini onun adına tamamlamayın. Karşınızdakini sanki anlıyormuş gibi davranmayın, ne demişlerse ve siz ne anlamışsanız bunu tekrarlayın ve doğru olup olmadığını sorun.

- Görme engeli olan insanlarla konuşurken "neyi kastettiğimi görüyor musun" veya tekerlekli sandalyedeki birine "şimdi hemen koşup bir yere yetişmem gerekir" türü ifadeler kullanmaktan çekinmeyin.

- Buna karşılık, örneğin "aksak”, "sakatlanmış”, “...'dan muzdarip”, “...kurbanı” veya "tekerlekli sandalyeye bağımlı” gibi olumsuz ifadeleri, 'topal' veya 'eksik' gibi deyimleri kullanmaktan kaçının. "Tekerlekli sandalye kullanıyor", "kas sorunu var" veya "duyamıyor" gibi, gerçekleri yansıtan basit ifadelerle yetinin. 
- Bir kişiye engeli/özrü hakkında soru sorarken nazik olun.

- $\quad$ Engelli bir kişinin yardıma intiyacı olduğu şeklinde bir izleniminiz varsa, hemen harekete geçmeden önce bu kişiye yardıma ihtiyacı olup olmadığını sorun.

- Kendisinden izin almadan, engelli bir kişinin tekerlekli sandalyesine, bastonuna vb. dokunmayın. Bunlar, söz konusu kişilerin kendi özel araçlarıdır.

- Sağır veya işitme güçlüğü olan bir kişinin size bakmasını istiyorsanız yavaşça koluna dokunabilir veya el sallayabilirsiniz.

- Kör veya ciddi düzeyde görme engelli bir kişiyle konuşacaksanız önce kendinizi tanıtın. Bu kişiye rehberlik etmek veya yönlendirmek gibi bir durumunuz varsa yön ve mesafeler konusunda net şeyler söyleyin; merdiven, zemin veya döşemede değişen yerler vb. konusunda gerekli uyarılarda bulunun (Rubin, 2002).

Bilgi ve Belge Yönetimi Bölümleri öğrencileri, ayrıca, engelli bireylere sunulan uyarlanmış teknoloji ürünleri -örneğin; görme engelliler için, ekran büyütücüler, ekran okuma sistemleri, Braille girdiçıktı donanımları vb; işitme engelliler için, ses ve konuşma çeviricileri, ses yükselticiler, sinyal sistemleri, TDD (iletişim cihazı) vb; fiziksel engelliler için, ekran klavyeleri, akıllı sözlükler, ses-yazı çeviricileri gibi- (Özürlü ve engelli 2000) konusunda bilgilendirilmelidirler. Bölümler, tüm engel türleri için uyarlanmış teknoloji laboratuvarları kurulmasını da düşünmelidir. Geleceğin kütüphanecilerine, kullanıcılarının bilgi ve teknoloji gereksinimlerine ilişkin eğitim ancak bu yolla verilebilir. Bölümler, çeşitli derslerde (bilgi depolama ve erişim, bilgisayar, İnternet, kütüphane otomasyonu, yönetim vb.) konu ile ilgili laboratuvar araştırmalarına da yer vermelidir. (Library, 2000).

Litetatürde, kütüphanecilik/bilgi ve belge yönetimi bölümle-rinde "rehabilitasyon kütüphaneciliği" alanında da eğitim verilmesi gerektiğini tartışan makalelere rastlanmaktadır. Rehabilitasyon kütüphaneciliğine, genel sağlık bilimleri alanında bir meslek olarak değinilmekte ve mesleğin, hasta destek sistemlerine (hasta, engelli hasta vb.) ve rehabilitasyon uzmanlarına sunulacak bilgi hizmetleri 
kapsamında önem taşıdığına vurgu yapılmaktadır. Sağlık bilimleri kütüphaneleri, hasta eğitimine, terapisine, boş zaman değerlendirmesine destek sağlayacak hizmet ve kaynakları sağlamada önemli görevler üstlenmişlerdir. BBY Bölümlerinin ders programlarına, hasta, engelli bireyler için özelleşmiş yardımcı teknolojilerle ve ödünç verme dermesiyle rehabilitasyon sistem ve hizmetleri sağlama konularının eklenmesi yararlı olacaktır (Haynes, 1989, s.15; Velleman, 1980).

Ayrıca, BBY Bölümleri, içinde bulundukları üniversite ve/veya fakültenin engelli öğrenci birimleri ile örneğin ülkemizdeki engelli odaklı kuruluşlarla (Özürlüler İdaresi Başkanlığı, Körler; Zihinsel Engelliler; Engelliler Federasyonları; Sakatlar Konfederasyonu) ortak çalışmalar yapabilir, özellikle engelli bireylerin toplum temelli güçlü kütüphane destek sistemlerine kavuşturulmasında çok önemli çalışmaları gerçekleştirebilirler.

\section{Sonuç}

Ülkelerin gelişmişlik düzeyleri, çağdaş uygarlık seviyeleri, engelli sorunlarının çözüme kavuşturulması ile doğru orantılıdır. Toplumdaki diğer bireyler gibi, engellilerin de aynı özlem ve gereksinimlere sahip oldukları gerçeğinden hareketle, kullanıcıları kim ve hangi engele sahip olursa olsun, kütüphaneciler, bilgi hizmetlerinde, uyarlanmış ve yardımcı teknolojilerle donatılmış merkezler oluşturmak ve özel erişim stratejileri geliştirmek için çaba gösterdiklerinde, salt engelli kullanıcıların değil, tüm bireylerin bilgi dünyasına girebilmelerine yardımcı olacaklardır. Bu anlamdaki güçlü ve ilgili ekibin oluşturulmasında, özellikle eğitim sürecinde duyarlılığın artırımasında, kuşkusuz, Bilgi ve Belge Yönetimi Bölümleri belirleyici rol oynayacaklardır.

\section{Kaynakça}


Akdeniz Üniversitesi Özel Gereksinimli Bireyler Için Araştırma, Uygulama ve Eğitim Merkezi. (2008). 25 Mart 2008 tarihinde http://www.akdeniz.edu.tr/ogm/index.html adresinden erişildi.

Akgül, M. K. ve Vercan, R. (2003). Özürlülerin işgücü niteliklerinin artırıması için eğitimlerinde bilgisayar teknolojilerinin kullanımı. 10 Nisan 2008 tarihinde http://www.tsd.org.tr/index.php?option =com_content\&task=view\&id=123\&ltemid=2997 adresinden erişildi.

Anadolu Üniversitesi Engelliler Araştırma Enstitüsü. 25 Mart 2008 tarihinde http://www.anadolu.edu.tr/akademik/ens_engars/ adresinden erişildi.

Ankara Üniversitesi Engelsiz Kampüs Projesi. 25 Mart 2008 tarihinde http://oeaum.ankara.edu.tr adresinden erişildi.

Avrupa Birliği'nin Engellilerle Illgili Stratejisi. 11 Mart 2008 tarihinde http://statik.iskur.gov.tr/tr/dis_iliskiler/ab_engelli_stratejisi.htm adresinden erişildi.

Barnes, C. (1997). A legacy of oppression: A history of disability in Western culture. L. Barton ve M. Oliver (Yay. Haz.). Disability Studies: Past, Present and Future içinde (ss. 4-24). 12 Nisan 2008 tarihinde http://www.leeds.ac.uk/disability-studies/archiveuk/ Barnes/chap1.pdf adresinden erişildi.

Becker, N.J. (2000), Service learning in the curriculum: preparing LIS students for the next millennium. Journal of Education for Library and Information Science, 41(4), 285-93.

Birleşmiş Milletler Engelli Hakları Sözleşmesi. 17 Nisan 2008 tarihinde http://www.ozevvakfi.org/isikyolu/pdf/bmehs.pdf adresinden erişildi.

Braithwaite, J. ve Mont, D. (2008). Disability and poverty: A survey of World Bank poverty assessments and implications. 4 Nisan 2008 tarihinde http://siteresources.worldbank.org/DISABILITY/ Resources/280658-172608138489/WBPovertyAssessments.pdf adresinden erişildi.

Butdisuwan, S. (1999). Information services to the disadvantaged person :A challenge for information professionals in Thailand. 65. 
IFLA Genel Konferansı, Bangkok'da sunulan bildiri. 2 Nisan 2008 tarihinde http://www.ifla.org/IV/ifla65/papers/022-132e.htm adresinden erişildi.

Carlos, D. J. (2005). Instruction in disability services and adaptive technology in schools of library and information science: A survey of the curriculum. 2 Nisan 2008 tarihinde http://etd.ils.unc.edu/dspace/bitstream/1901/170/1/deborahcarlos. pdf adresinden erişildi.

Commitment to an International Convention on the Rights of Disabled Persons. 10 Nisan 2008 tarihinde http://www.dpa.org.sg/ publication/dpaaug2001/p6.htm adresinden erişildi.

Engelsiz ODTÜ Koordinatörlüğü. 25 Mart 2008 tarihinde http://www.engelsiz.metu.edu.tr/ adresinden erişildi.

Ershova, T. V. ve Hohlov, Y. E. (2000). Migrating from the library of today to the library of tomorrow: re- or e-volution? 66. IFLA Genel Konferansı, Küdüs'de sunulan bildiri. 28 Mart 2008 tarihinde http://www.ifla.org/IV/ifla66/papers/063-110e.htm adresinden erişildi.

Galler, A. M. (1997). The inclusion of library services to disadvantaged persons in library school curricula: A survey. IFLA Journal, 23, 365-370.

Hacettepe Üniversitesi Engelliler Araştırma ve Uygulama Merkezi. (2008). 25 Mart 2008 tarihinde http://www.engelsiz.hacettepe. edu.tr adresinden erişildi.

Haynes, D. E. (1989). The switch library: New service in rehabilitation librarianship. Bulletin of the Medical Library Association, 77(1), 15-18.

İstanbul Üniversitesi Özürlüler Araştırma ve Uygulama Merkezi. 25 Mart 2008 tarihinde http://www.iu.edu.tr/merkezler/oaum/ index.htm adresinden erişildi.

Karataş, K. (2002). Engellilerin toplumla bütünleşme sorunları: Bir sosyal politika yaklaşımı. Ufkun Ötesi Bilim Dergisi, 2(2), 43-55.

Kavanagh, R. ve Sköld, B. C. (2005). Libraries for the blind in the information age: Guidelines for development. Amsterdam: IFLA. 
26 Mart 2008 tarihinde http://www.ifla.org/VII/s31/pub/

Profrep86.pdf. adresinden erişildi.

Library and information services for individuals with disabilities: An NCLIS hearing in Washington, DC July 8, 1999. (2000). Washington, DC: U.S. National Commission on Libraries and Information.

Norton, M. J. (1992). Effective bibliographic instruction for deaf and hearing-impaired college students. Library Trends, 41(1), 118-150. 28 Mart 2008 tarihinde http://people.rit.edu/easi/lib/ oppo6.htm adresinden erişildi.

Okinawa Charter on Global Information Society. Okinawa, July 22, 2000. (2000). 12 Nisan 2008 tarihinde http://www.g8.utoronto.ca/ summit/2000okinawa/gis.htm adresinden erişildi.

Özürlü ve engelli vatandaşlar için hizmet: Çalışma belgesi. (2000). Türkiye Bilgi Toplumu 2010, [CD içinde]. Ankara: T.C. Ulaştırma Bakanlığı - Türkiye Ulusal Enformasyon Altyapısı (TUENA) Proje Ofisi.

Özürlüler ve Bazı Kanun ve Kanun Hükmünde Kararnamelerde Değişiklik Yapılması Hakkında Kanun. (2005). Resmi Gazete, 07.07.2005, sayı, 25868.

Özürlüler ve yaşam algısı 3 Nisan 2008 tarihinde http://www.psikolojikdanisma.net/ozurluler.htm adresinden erişildi.

Perelman, D. (2007). Program aims to make technology more accessible. 12 Nisan 2008 tarihinde http://www.nysforum. org/committees/itaccessibility/newsletters/april07-accessnewsletter.aspx adresinden erişildi.

Rubin, R. J. (2002). Serving people with disabilities. Different Voices, Common Quest. ALA OLOS Preconference'da sunulan bildiri. 4 Nisan 2008 tarihinde http://staging.ala.org/ala/ aboutala/offices/olos/outreachresource/docs/people_with_disabiliti es.pdf adresinden erişildi. 
Russel, M. (2003). Too many human rights. 7 Nisan 2008 tarihinde http://www.globalpolicy.org/socecon/un/2003/0714rights.htm adresinden erişildi.

Sakat Kişilerin Hakları Beyannamesi: Birleşmiş Milletler Genel Kurulu'nun 9 Aralık 1975'deki Toplantısında kabul edilen 3447 sayılı Sakat Kişilerin Hakları Beyannamesi. (1975). 5 Nisan 2008 tarihinde http://www.tsd.org.tr/index.php?option=com_content\& task=view\&id=314\&ltemid=1362 adresinden erişildi.

Sarıoğlu, S. Özürlülük, sosyal hizmetler ve küreselleşme. 5 Nisan 2008 tarihinde http://www.sosyalhizmetuzmani.org/ozurluluk kuresellesme.doc adresinden erişildi.

Süleyman Demirel Üniversitesi Engelliler Araştırma ve Uygulama Merkezi. 25 Mart 2008 tarihinde http://enar.sdu.edu.tr/ adresinden erişildi.

Şahin, H. (2004). Engelilik kimin sorunu? Bireyin mi, toplumun mu? Öz-Veri, 1(1), 40-50.

Velleman, R. A. (1980). Library service to the disabled an annotated bibliography of journals and newsletters. Serials Libraries, 5(2), 49-60.

Walling, L. L. (2004). Educating students to serve information seekers with disabilities. Journal of Education for Library and Information Science, 45(2), 137-148.

World Health Organization-WHO. (2008). 5 Nisan 2008 tarihinde http://www.who.int/en/ adresinden erişildi.

Yontz, E., ve de la Peña McCook, K. (2003). Service-Learning and LIS Education. Journal of Education for Library \& Information Science, 44(1), 58.

Yükseköğretim Kurumları Özürlüler Danışma ve Koordinasyon Yönetmeliği. (2006). Resmi Gazete, 20.06.2006. sayı, 26204. 